\title{
Putative Effects of Nutritive Polyphenols on Bone Metabolism In Vivo-Evidence from Human Studies
}

\author{
Katharina Austermann ${ }^{1}$, Natalie Baecker ${ }^{2}$, Peter Stehle ${ }^{1}$ (D) and Martina Heer ${ }^{1,2, *(D)}$ \\ 1 Department of Nutrition and Food Sciences, Nutritional Physiology, University of Bonn, \\ 53115 Bonn, Germany; kataust@uni-bonn.de (K.A.); pstehle@uni-bonn.de (P.S.) \\ 2 IUBH International University, 53604 Bad Honnef, Germany; n.baecker@IUBH-fernstudium.de \\ * Correspondence: drmheer@aol.com; Tel.: +49-228-73-2021
}

Received: 21 March 2019; Accepted: 17 April 2019; Published: 18 April 2019

\begin{abstract}
For the prevention and treatment of bone loss related diseases, focus has been put on naturally derived substances such as polyphenols. Based on human intervention studies, this review gives an overview of the effects of dietary significant polyphenols (flavonoids, hydroxycinnamic acids, and stilbenes) on bone turnover. Literature research was conducted using PubMed database and articles published between 01/01/2008 and 31/12/2018 were included (last entry: 19/02/2019). Randomized controlled trials using oral polyphenol supplementation, either of isolated polyphenols or polyphenols-rich foods with healthy subjects or study populations with bone disorders were enclosed. Twenty articles fulfilled the inclusion criteria and the average study quality (mean Jadad score: 4.5) was above the pre-defined cut-off of 3.0. Evidence from these studies does not allow an explicit conclusion regarding the effects of dietary important polyphenols on bone mineral density and bone turnover markers. Differences in study population, habitual diet, lifestyle factors, applied polyphenols, used doses, and polyphenol bioavailability complicate the comparison of study outcomes.
\end{abstract}

Keywords: polyphenols; antioxidants; flavonoids; bone; osteoporosis; bone loss

\section{Introduction}

The human skeleton is continuously remodeled throughout life by osteoclast- (bone resorbing cells) and osteoblast (bone forming cells) activities [1]. Bone remodeling ensures mineral homeostasis, maintains the integrity of the skeleton, and is responsible for removal and repair of damaged tissue [2]. The underlying close communication and interaction between osteoclasts and osteoblasts consist of four consecutive phases: activation, resorption, formation, and termination/resting [2,3]. In brief, during the activation phase, an initiating remodeling signal is detected by bone cell receptors supporting the migration of partially differentiated mononuclear preosteoclasts to the bone surface. Multinucleated osteoclasts are then formed promoting resorption of bone mass. In the third phase mononuclear cells prepare the bone surface for the osteoblast-mediated formation and initiate osteoblast differentiation and -migration. Osteoblasts replace the removed bone with an equal quantity of new bone. Flattened lining cells cover the surface and mineralization occurs [2,3].

The main regulators of bone turnover are mechanical strain, systemic factors (e.g., calcitriol, calcitonin, growth hormone, insulin-like growth factor 1, glucocorticoids, and sex hormones), and local factors (e.g., the osteoprotegerin [OPG] - receptor activator of nuclear factor-kappa B ligand [RANKL] - receptor activator of nuclear factor-kappa B [RANK] system) [4-6].

Aside from these, the physiological balance between oxidants and antioxidants (redox status) also seems to be important for the maintenance of a balanced osteoclast- and osteoblast activity and therefore a successful bone remodeling process (Figure 1) [7,8]. Several in vitro and animal studies 
have shown that reactive oxygen species (ROS) production is involved in the regulation of bone status and in mineral tissue homeostasis mainly by promoting bone resorption [9-12]. Moreover, ROS act as signaling molecules in several signaling pathways in bone cells and enhance osteoclastogenesis (Figure 1) [8].

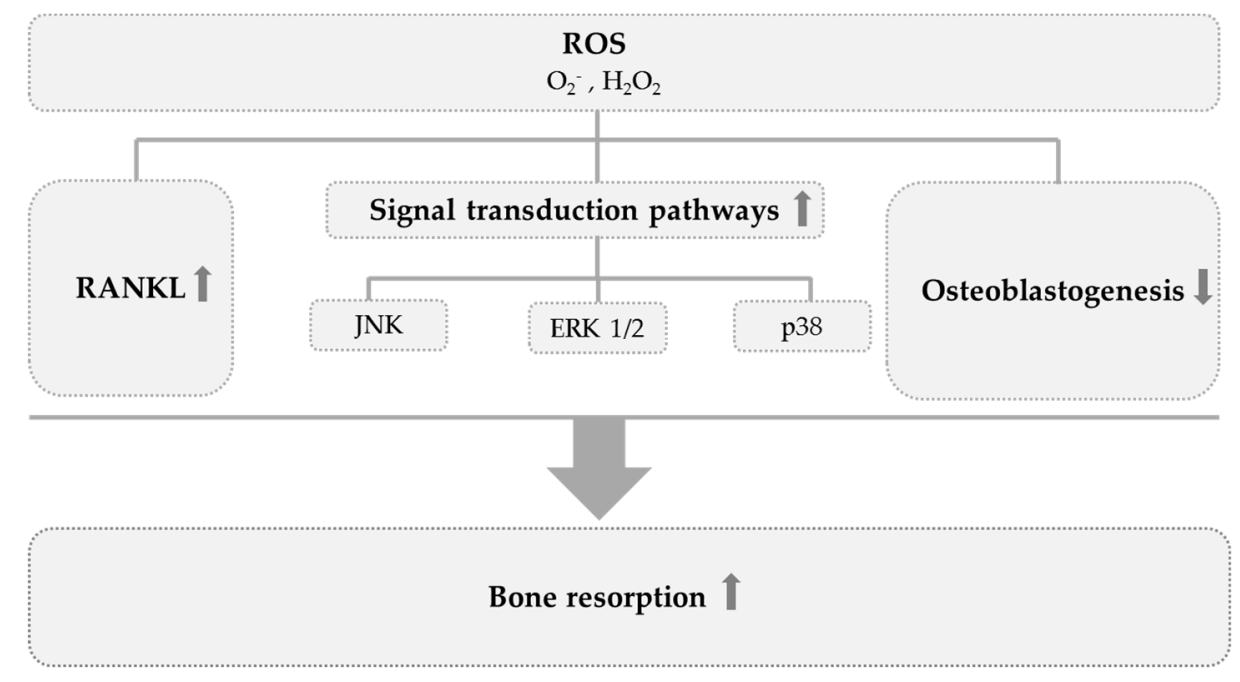

Figure 1. Impact of reactive oxygen species (ROS) on bone turnover [8-14]. ROS promote bone resorption by enhancing receptor activator of nuclear factor-kappa B ligand [RANKL]-induced osteoclast activity, by activation of osteoclastogenesis related signal transduction cascades (c-Jun N-terminal kinase (JNK), p38 mitogen-activated protein kinases (p38), extracellular signal-regulated kinase (ERK 1/2)), and by suppressing osteoblastogenesis. $\uparrow$, activation; $\downarrow$ inhibition.

Under normal physiological conditions the ROS production by osteoclasts contributes to bone remodeling by stimulating the destruction of calcified tissue $[13,14]$. Exceeding ROS production and osteoclastic activity, however, were observed in different skeletal pathologies such as osteoporosis and bone fractures [15]. Several studies indicate a relation between oxidative stress and bone loss [16-19]. Oxidative stress associated with increased lipid peroxidation seems to enhance bone resorption resulting in reduced bone mineral density (BMD) [16,17]. A higher value of the superoxide dismutase (SOD)/glutathione peroxidase (GPx) ratio was observed in subjects with osteoporosis [18]. SOD generates $\mathrm{H}_{2} \mathrm{O}_{2}$ by removing superoxide and therefore has to collaborate with $\mathrm{H}_{2} \mathrm{O}_{2}$-removing enzymes like GPx or catalase to prevent oxidative stress [20]. The imbalance created by an altered SOD/GPx ratio leads to an increase in $\mathrm{H}_{2} \mathrm{O}_{2}$ levels [21]. High $\mathrm{H}_{2} \mathrm{O}_{2}$ levels promote osteoclastic differentiation and inhibit osteoblastic differentiation, which results in bone resorption [22,23].

Numerous observational studies have shown that intake of several portions of fruits and vegetables per day ( 240 — 400 g) is associated with greater BMD and decreased fracture risk [24-26]. Recent reviews summarizing observational studies in Asia conclude that the consumption of soy isoflavonoids is inversely associated with the incidence of hip fractures and osteoporosis risk in postmenopausal women $[27,28]$. Epidemiological studies focusing on tea drinking (green- and black tea) show adverse results with respect to bone health [29-33]. Observational studies evaluating the effects of habitual tea drinking on bone health showed, however, inconsistent results in both men and women [34]. The generally positive effects of fruit-, vegetable-, and tea consumption seem to be partly attributed to their content of alkaline-precursors which contribute to neutralizing acid loads from other components of the diet so that the skeleton is not used as a buffer to resorb and neutralize acid loads [35].

More important might be their content of active phytochemical compounds, such as polyphenols [36-39]. Due to their antioxidative potential, polyphenols may protect cells against oxidative damage induced by ROS and thereby attenuate the risk for the development of degenerative diseases such as cardiovascular diseases, cancer, diabetes, and osteoporosis [40,41]. In vitro- as well as 
animal studies suggest that polyphenols, apart from their antioxidative properties, affect bone metabolism by anti-inflammatory actions, suppression of osteoclastogenesis, and activation of osteoblastogenesis via different bone related pathways [42-50].

Polyphenols can be distinguished according to their chemical structure (number and arrangement of carbon atoms). Based on that, they can be classified into nine subgroups (Figure 2) [51]. Depending on the amount of vegetables and fruits consumed, the daily intake of polyphenols sums up to $>500 \mathrm{mg} / \mathrm{day}$ (five portions of vegetables and fruits per day). The additional consumption of tea (green-, black-, white-, and Oolong tea), coffee, and cocoa can lead to intakes up to 1000—1500 mg/day [52].

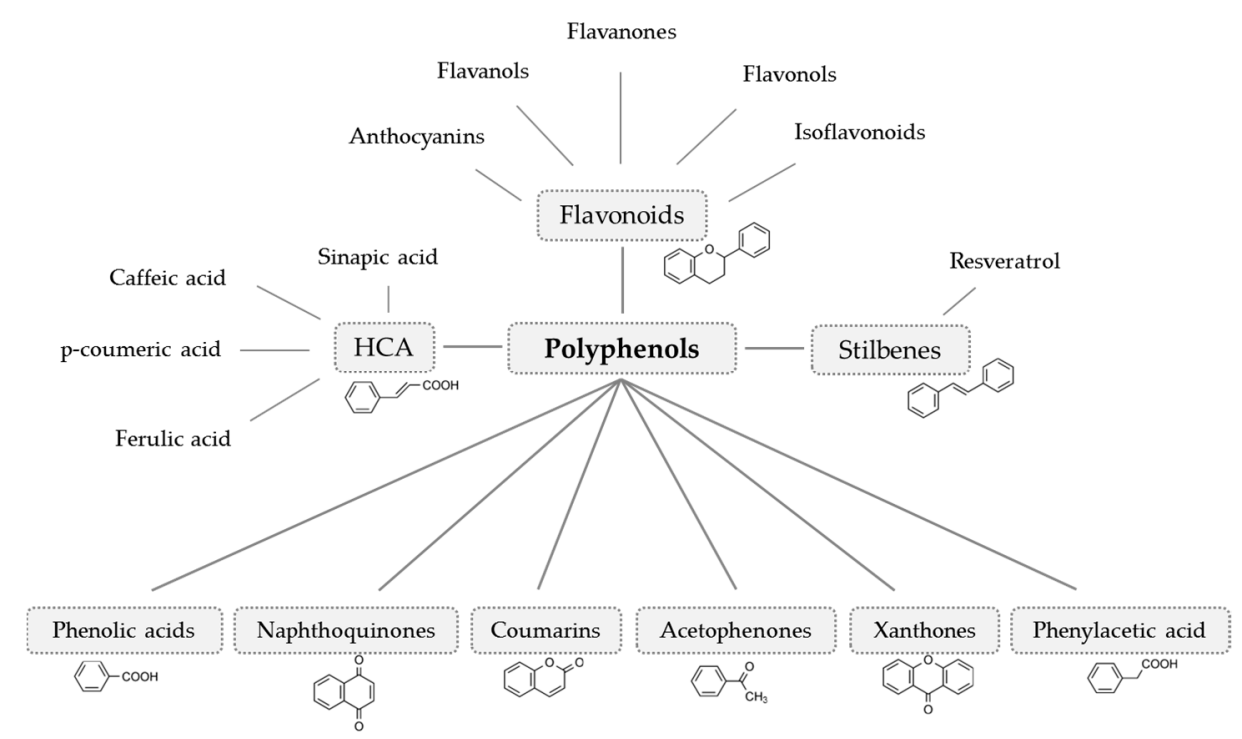

Figure 2. Polyphenol classification (modified from Crozier et al. [51]) The nine polyphenol subgroups are classified according to their chemical structure and are found throughout the plant kingdom. HCA, hydroxycinnamic acids.

Relevant nutritive polyphenol subgroups are flavonoids, hydroxycinnamic acids, and stilbenes [51]. Flavonoids are found in a variety of fruits, vegetables, herbs, and beverages. [53]. The most abundant flavanols are (+)-catechin, (-)-epicatechin (EC), (+)-gallocatechin (GC), and (-)-epigallocatechin (EGC) and the gallic acid esters (-)-epicatechin gallate (ECG) and (-)-epigallocatechin gallate (EGCG). Tea (camellia sinensis) is the most quantitative source of these compounds worldwide [53]. The predominating flavonols are quercetin, kaempferol, myricetin, and isorhamnetin [53]. They usually occur as glycosides and are mainly located in the flowers, leaves, and outer parts of the plant as peel or skin. Important dietary sources are onions, apples, and leafy vegetables [54,55]. Flavanones are mainly found in citrus fruits [56]. The dominant flavanone in lemon, mandarin, and sweet orange is the rutinoside hesperidin. Sour oranges and grapefruits are dominated by the neohesperidoside naringin [57]. Major flavones are luteolin and apigenin. They are usually present as O- and C-glycosides. Aglycons of flavones are not found in fresh plants but can occur after processing [53]. Luteolin and apigenin have been identified in several vegetables such as celery and artichoke and in different herbs such as rosemary, thyme, or parsley [58,59]. Isoflavonoids, such as genistein, daidzein, and glabridin are also referred to as phytoestrogens due to their estrogenic activity. Important dietary sources for genistein and daidzein are legumes such as soybeans [60]. Glabridin is an isoflavan found in the licorice root [61]. Anthocyanins are responsible for the red, blue, or purple color of several fruits and vegetables such as plums, cherries, raspberries, blackberries, blackcurrants, beetroot, and red cabbage [62]. Aglycons, such as cyanidin or delphinidin are rarely found in plants and most commonly bounded sugars are glucose, galactose, rhamnose, and arabinose, usually as 3-glycosides [63]. Hydroxycinnamic acids (HCA) are also widely found in the human diet and main derivates are caffeic-, ferulic-, $\varrho$-coumaric,and sinapic acid. They usually occur as esters or glycosides of quinic acid. O-glycosylated ferulic-, 
caffeic-, and $\rho$-coumaric acids are present in tomatoes [64]. Other fruits containing hydroxycinnamic acids are plums, blueberries, cherries, and apples [65]. Stilbenes are present in vegetables and fruits such as spinach, berries, apples, and grapes. In plants, they are produced in response to stress, injury, or disease. The parent compound resveratrol can occur in cis- and trans configuration, as glucosides, aglycones, monomers, or polymers [66]. In higher concentrations resveratrol can be found in red grapes and, thus, in red wine, depending on the species [67].

The role of nutritive polyphenols in maintaining bone health is not finally resolved. Indeed, a final conclusion of the qualitative and quantitative role of nutritive polyphenols on bone metabolism and bone health can only be made on the basis of intervention studies. Thus, the aim of this literature review is to summarize and evaluate results of recently published human intervention studies investigating the effects of nutritive polyphenols, either as single substrates or as ingredients of foods, on bone metabolism.

\section{Methods}

The systematic literature search (U.S. National Library of Medicine National Institutes of Health online database PubMed) sought to identify all eligible English articles published between 2008 and 2018 in peer-review journals (last entry: 19/02/2019) with a clear focus on the major polyphenol subgroups. The following search terms were used and at least one of the terms in each of the following four lists had to be present in the title and/or abstract of the article: (1) clinical, experimental, human, in vivo, intervention; (2) bone, bone turnover, bone markers, bone loss; (3) nutrition, nutritional, supplementation, oral; (4) polyphenols, flavonoids, flavanols, flavonols, flavanones, flavones, isoflavonoids, isoflavones, anthocyanins, stilbenes, hydroxycinnamic acids. The following PubMed filters were applied: publication date (from 01/01/2008 to 31/12/2018) and species (humans). In addition, reference lists of articles identified during the literature search have been checked for complete identification of eligible articles.

\subsection{Article Selection}

Studies meeting the following inclusion criteria were included in the evaluation: (a) randomized controlled trials; (b) oral polyphenol supplementation; (c) supplementation of isolated polyphenols or polyphenol-rich foods; (d) healthy subjects or study populations with bone loss related diseases (e) outcomes: BMD or bone turnover markers; (f) publication date: 2008-2018. As shown in Figure 3, 20 articles were finally included in this review.

Two independent and experienced reviewers manually screened the title and/or the abstract of the articles that were flagged during the literature search for adherence to the above eligibility criteria. When the reviewers disagreed about the eligibility of a particular article the whole text of the article was read and a consensus decision was reached.

\subsection{Data Presentation}

Data extraction followed a predefined protocol. Human trials were categorized according to the polyphenol subclass (flavanols, flavonols, flavanones, flavones, isoflavonoids, anthocyanins, hydroxycinnamic acids, stilbenes) administered, or in the case of food consumption, according to the dominant polyphenol ingredient of the food items under investigation. To evaluate study quality the Jadad score was calculated for each study included [68]. In this score randomization, blinding, and dropout description are assessed. The scale ranges from 0 (low quality) to 5.0 (high quality) [68]. Scores above a defined cut-off of 3.0 indicate that reliable conclusions can be drawn. 


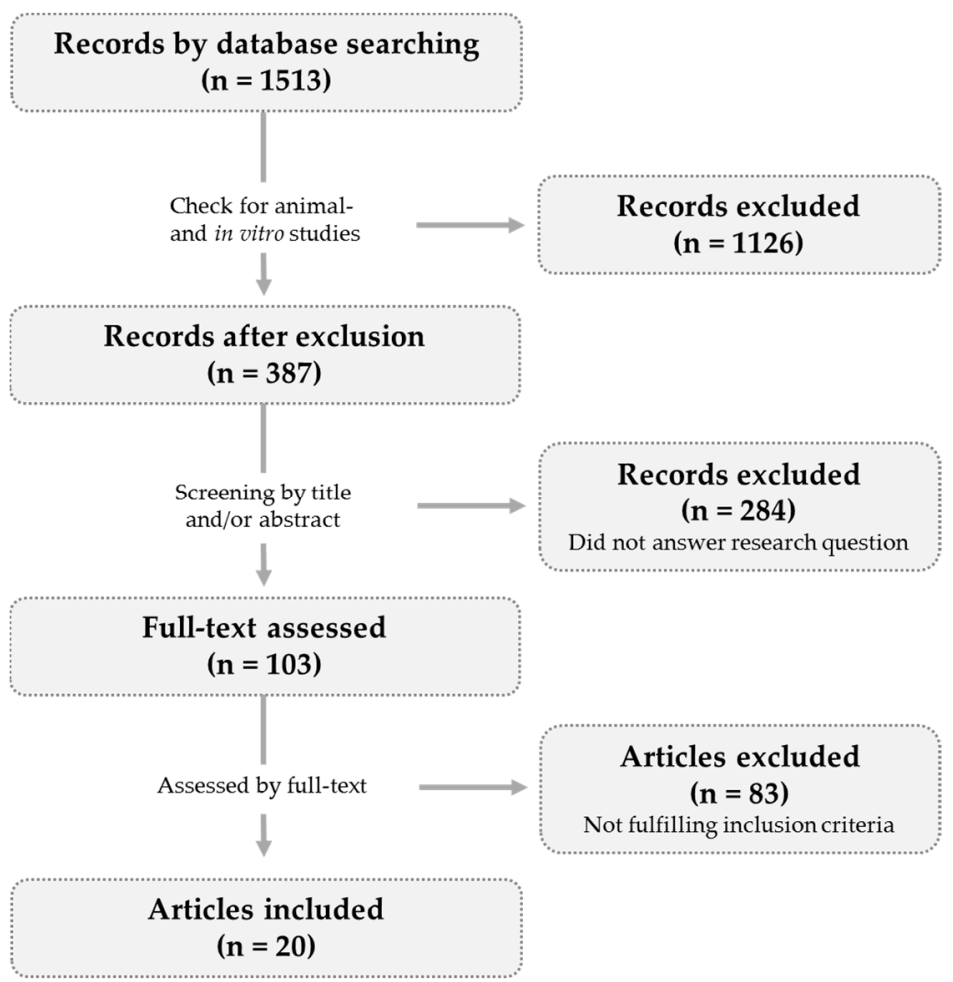

Figure 3. Study selection diagram. The literature search revealed 1513 hits (PubMed filters: publication date (from 01/01/2008 to 31/12/2018) and species (humans). After removal of further animal- and in vitro studies 387 records were screened. Full-text was assessed for 103 records and 83 articles did not meet the inclusion criteria. Twenty articles were included.

\section{Results and Discussion}

Study details of the included studies are summarized in Table 1. The volunteer characteristics, intervention protocols, characterization of the control group, study duration, and observed effects on bone are shown. Most of the human trials were performed in postmenopausal women and participant numbers range from twelve to 431 . Time of intervention varied between eight weeks and three years and health status of volunteer collectives differed. 
Table 1. Overview of human intervention studies included.

\begin{tabular}{|c|c|c|c|c|c|c|c|c|c|c|}
\hline & \multicolumn{4}{|c|}{ Participants } & \multirow{2}{*}{$\begin{array}{c}\text { Intervention } \\
\text { (Powder/Food Item) }\end{array}$} & \multirow[b]{2}{*}{ Control Group } & \multirow[b]{2}{*}{ Duration } & \multirow{2}{*}{$\begin{array}{c}\text { Power } \\
\text { Analysis }\end{array}$} & \multirow[b]{2}{*}{ Effects on Bone } & \multirow{2}{*}{$\begin{array}{l}\text { Jadad } \\
\text { Score }\end{array}$} \\
\hline & Number & $\begin{array}{c}\text { Age } \\
\text { (Year) }\end{array}$ & Gender & Health Status & & & & & & \\
\hline Flavanols & & & & & & & & & & \\
\hline $\begin{array}{l}\text { Dostal et al. } 2016 \\
\text { [69] }\end{array}$ & 121 & $50-70$ & Female & $\begin{array}{c}\text { Overweight/obese, } \\
\text { postmenopausal, } \\
\text { high breast cancer risk }\end{array}$ & $\begin{array}{c}\text { GTE } \\
(843 \mathrm{mg} \text { EGCG/d) }\end{array}$ & $\begin{array}{l}\text { Overweight/obese, } \\
\text { postmenopausal women with } \\
\text { high breast cancer risk }\end{array}$ & 1 year & Yes $(80 \%)$ & Total body BMD $\leftrightarrow$ & 5 \\
\hline $\begin{array}{l}\text { Shen et al. } \\
2012[70]\end{array}$ & 171 & $>50$ & Female & $\begin{array}{l}\text { Postmenopausal, } \\
\text { osteopenic }\end{array}$ & $\begin{array}{c}\text { GTE } \\
(500 \mathrm{mg} / \mathrm{d})\end{array}$ & $\begin{array}{l}\text { Postmenopausal, } \\
\text { osteopenic women }\end{array}$ & 6 months & $\begin{array}{c}\text { Yes } \\
(85-90 \%)\end{array}$ & $\begin{array}{c}\text { bAP } \uparrow \\
\text { TRAP } \leftrightarrow \\
\text { bAP/TRAP ratio } \uparrow\end{array}$ & 5 \\
\hline $\begin{array}{c}\text { Flavonols } \\
\text { Law et al. } 2016 \\
\text { [71] }\end{array}$ & 30 & $40-80$ & $\begin{array}{l}\text { Female, } \\
\text { male }\end{array}$ & Healthy & $\begin{array}{l}\text { Onion juice } \\
(100 \mathrm{ml} / \mathrm{d})\end{array}$ & Healthy men and women & 8 weeks & No & $\begin{array}{c}\text { Total body BMD } \leftrightarrow \\
\text { bAP } \downarrow \\
\text { PTH } \leftrightarrow \\
\text { Calcium } \leftrightarrow\end{array}$ & 5 \\
\hline $\begin{array}{c}\text { Flavanones } \\
\text { Martin et al. } \\
2016 \\
{[72]}\end{array}$ & 12 & $>50$ & Female & $\begin{array}{l}\text { Postmenopausal, } \\
\text { healthy }\end{array}$ & $\begin{array}{l}\text { Hesperidin } \\
(500 \mathrm{mg})\end{array}$ & $\begin{array}{l}\text { Postmenopausal, } \\
\text { healthy women }\end{array}$ & 3 months & $\begin{array}{c}\text { Yes } \\
(80 \%)\end{array}$ & $\begin{array}{l}\mathrm{bAP} \leftrightarrow \\
\mathrm{DPD} \leftrightarrow\end{array}$ & 5 \\
\hline Isoflavonoids & & & & & & & & & & \\
\hline $\begin{array}{c}\text { Alekel et al. 2010; } \\
\text { Shedd-Wise et al. } 2011 \\
\text { [73,74] }\end{array}$ & 255 & $46-65$ & Female & $\begin{array}{l}\text { Postmenopausal, } \\
\text { healthy }\end{array}$ & $\begin{array}{l}\text { Soy isoflavonoids } \\
\text { (80 and } 120 \mathrm{mg} / \mathrm{d} \text { ) }\end{array}$ & $\begin{array}{l}\text { Postmenopausal, } \\
\text { healthy women }\end{array}$ & 3 years & $\begin{array}{c}\text { Yes } \\
(94 \%)\end{array}$ & $\begin{array}{c}\text { Total body BMD } \leftrightarrow \\
\text { spine BMD } \leftrightarrow \\
\text { femur BMD } \leftrightarrow \\
\text { neck BMD } \leftrightarrow \\
\text { Femur BMD } \uparrow\end{array}$ & 5 \\
\hline $\begin{array}{l}\text { Arcoraci et al. 2017; } \\
\text { Marini et al. 2008 } \\
\text { [75-77] }\end{array}$ & 389 & $49-67$ & Female & $\begin{array}{l}\text { Postmenopausal, } \\
\text { osteopenic }\end{array}$ & $\begin{array}{l}\text { Genistein } \\
(54 \mathrm{mg} / \mathrm{d})\end{array}$ & $\begin{array}{l}\text { Postmenopausal, osteopenic } \\
\text { women }\end{array}$ & 2 years & Yes $(80 \%)$ & $\begin{array}{c}\text { spine BMD } \uparrow \\
\text { PYD } \downarrow \\
\text { DPD } \downarrow \\
\text { bAP } \uparrow \\
\text { RANKL } \downarrow \\
\text { OPG } \uparrow\end{array}$ & 5 \\
\hline $\begin{array}{l}\text { Brink et al. } 2008 \\
\quad[78]\end{array}$ & 237 & $53 \pm 3$ & Female & $\begin{array}{l}\text { Early postmenopausal, } \\
\text { healthy }\end{array}$ & $\begin{array}{c}\text { Isoflavonoid enriched } \\
\text { foods } \\
(110 \mathrm{mg} \text { isoflavonoid } \\
\text { aglycones/d) }\end{array}$ & $\begin{array}{l}\text { Early postmenopausal, } \\
\text { healthy women }\end{array}$ & 1 year & Yes $(84 \%)$ & $\begin{array}{c}\text { Total body BMD } \leftrightarrow \\
\text { bone markers } \leftrightarrow\end{array}$ & 5 \\
\hline $\begin{array}{c}\text { Kenny et al. } 2009 \\
\text { [79] }\end{array}$ & 131 & $>60$ & Female & $\begin{array}{l}\text { Postmenopausal, } \\
\text { healthy }\end{array}$ & $\begin{array}{c}\text { Isoflavonoids } \\
(105 \mathrm{mg} / \mathrm{d})\end{array}$ & $\begin{array}{l}\text { Postmenopausal, } \\
\text { healthy women }\end{array}$ & 1 year & No & $\begin{array}{c}\text { Total body BMD } \leftrightarrow \\
\text { femur BMD } \leftrightarrow \\
\text { spine BMD } \leftrightarrow \\
\text { wrist BMD } \leftrightarrow\end{array}$ & 4 \\
\hline $\begin{array}{c}\text { Sathyapalan et al. } 2016 \\
\text { [80] }\end{array}$ & 200 & $>50$ & Female & Early postmenopausal & $\begin{array}{l}\text { Isoflavonoids } \\
(66 \mathrm{mg} / \mathrm{d})\end{array}$ & Early postmenopausal women & 6 months & Yes $(95 \%)$ & $\begin{array}{l}\text { BCTX } \downarrow \\
\text { P1NP } \downarrow\end{array}$ & 5 \\
\hline $\begin{array}{c}\text { Tai et al. } 2012 \\
\text { [81] }\end{array}$ & 431 & $45-65$ & Female & $\begin{array}{l}\text { Postmenopausal with } \\
\text { bone loss }\end{array}$ & $\begin{array}{l}\text { Isoflavonoids } \\
(300 \mathrm{mg} / \mathrm{d})\end{array}$ & $\begin{array}{l}\text { Postmenopausal women with } \\
\text { bone loss }\end{array}$ & 2 years & Yes $(80 \%)$ & $\begin{array}{c}\text { Femur BMD } \leftrightarrow \\
\text { Bone markers } \leftrightarrow\end{array}$ & 5 \\
\hline $\begin{array}{l}\text { Vupadhyayula et al. } 2009 \\
\text { [82] }\end{array}$ & 203 & $>50$ & Female & $\begin{array}{c}\text { Postmenopausal, } \\
\text { healthy }\end{array}$ & $\begin{array}{l}\text { Isoflavonoids } \\
(90 \mathrm{mg} / \mathrm{d})\end{array}$ & $\begin{array}{l}\text { Postmenopausal, } \\
\text { healthy women }\end{array}$ & 2 years & Yes $(80 \%)$ & $\begin{array}{l}\text { Spine BMD } \leftrightarrow \\
\text { Femur BMD } \leftrightarrow\end{array}$ & 4 \\
\hline $\begin{array}{l}\text { Wong et al. } 2009 \\
\text { [83] }\end{array}$ & 403 & $40-60$ & Female & $\begin{array}{l}\text { Climacteric, } \\
\text { healthy }\end{array}$ & $\begin{array}{l}\text { Soy isoflavonoids } \\
(80 \text { and } 120 \mathrm{mg} / \mathrm{d})\end{array}$ & $\begin{array}{l}\text { Climacteric, } \\
\text { healthy women }\end{array}$ & 2 years & Yes $(80 \%)$ & $\begin{array}{c}\text { Total Body BMD } \uparrow \\
(120 \mathrm{mg} / \mathrm{d}) \\
\text { Bone markers } \leftrightarrow\end{array}$ & 5 \\
\hline
\end{tabular}


Table 1. Cont.

\begin{tabular}{|c|c|c|c|c|c|c|c|c|c|c|}
\hline & \multicolumn{4}{|c|}{ Participants } & \multirow{2}{*}{$\begin{array}{c}\text { Intervention } \\
\text { (Powder/Food Item) }\end{array}$} & \multirow[b]{2}{*}{ Control Group } & \multirow[b]{2}{*}{ Duration } & \multirow{2}{*}{$\begin{array}{c}\text { Power } \\
\text { Analysis }\end{array}$} & \multirow[b]{2}{*}{ Effects on Bone } & \multirow[b]{2}{*}{$\begin{array}{l}\text { Jadac } \\
\text { Score }\end{array}$} \\
\hline & Number & $\begin{array}{c}\text { Age } \\
\text { (Year) }\end{array}$ & Gender & Health Status & & & & & & \\
\hline Anthocyanins & & & & & & & & & & \\
\hline $\begin{array}{c}\text { Hooshmand et al. } 2011 \\
\text { and 2014 } \\
{[84,85]}\end{array}$ & 160 & $>50$ & Female & $\begin{array}{l}\text { Postmenopausal, } \\
\text { osteopenic }\end{array}$ & $\begin{array}{l}\text { Dried plums } \\
(100 \mathrm{~g} / \mathrm{d})\end{array}$ & $\begin{array}{l}\text { Postmenopausal, } \\
\text { osteopenic women }\end{array}$ & 1 year & No & $\begin{array}{c}\text { Ulna BMD } \uparrow \\
\text { Spine BMD } \uparrow \\
\text { OPG } \leftrightarrow \\
\text { Sclerostin } \leftrightarrow\end{array}$ & 3 \\
\hline $\begin{array}{c}\text { Hooshmand et al. } 2016 \\
\text { [86] }\end{array}$ & 48 & $65-79$ & Female & $\begin{array}{l}\text { Postmenopausal, } \\
\text { osteopenic }\end{array}$ & $\begin{array}{l}\text { Dried plums } \\
\text { (50 and } 100 \mathrm{~g} / \mathrm{d})\end{array}$ & $\begin{array}{l}\text { Postmenopausal, } \\
\text { osteopenic women }\end{array}$ & 6 months & No & $\begin{array}{c}\text { Total BMD } \uparrow \\
\text { TRAP } \downarrow \\
\text { Spine BMD } \leftrightarrow\end{array}$ & 3 \\
\hline $\begin{array}{c}\text { Simonavice et al. } 2014 \\
\text { [87] }\end{array}$ & 27 & $64 \pm 7$ & Female & $\begin{array}{c}\text { Postmenpausal, } \\
\text { breast cancer survivors }\end{array}$ & $\begin{array}{l}\text { Dried plums } \\
\quad(90 \mathrm{~g} / \mathrm{d})\end{array}$ & $\begin{array}{l}\text { Postmenpausal women, } \\
\text { breast cancer survivors }\end{array}$ & 6 months & Yes $(80 \%)$ & $\begin{array}{c}\text { Femur BMD } \leftrightarrow \\
\text { Forearm BMD } \leftrightarrow \\
\text { Bone markers } \leftrightarrow\end{array}$ & 3 \\
\hline $\begin{array}{c}\text { Ornstrup et al. } 2014 \\
\text { [88] }\end{array}$ & 74 & $49 \pm 6$ & Male & $\begin{array}{l}\text { Obese, } \\
\text { metabolic syndrome }\end{array}$ & $\begin{array}{c}\text { Resveratrol } \\
(150 \text { and } 1000 \mathrm{mg} / \mathrm{d})\end{array}$ & $\begin{array}{l}\text { Obese men with } \\
\text { metabolic syndrome }\end{array}$ & 16 weeks & Yes $(80 \%)$ & $\begin{array}{c}\text { Spine BMD } \uparrow \\
(1000 \mathrm{mg} / \mathrm{d}) \\
\mathrm{bAP} \uparrow \\
(1000 \mathrm{mg} / \mathrm{d}) \\
\text { OPG } \leftrightarrow \\
\text { P1NP } \leftrightarrow \\
\text { CTX } \leftrightarrow \\
\text { NTX }\end{array}$ & 5 \\
\hline
\end{tabular}

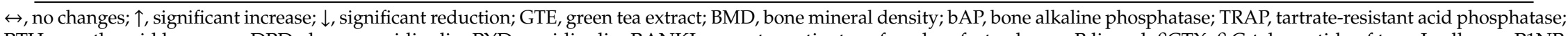
PTH, parathyroid hormone; DPD, desoxypyridinolin; PYD, pyridinolin; RANKL, receptor activator of nuclear factor-kappa B ligand; BCTX, B C-telopeptide of type I collagen; P1NP, aminoterminal propeptide of type I collagen; OPG, osteoprotegerin; CTX, C-telopeptide of type I collagen; NTX, N-telopeptide of type I collagen; d: day. 
The number of intervention studies conducted for the different polyphenol subgroups differ broadly (one study each for flavanols and stilbenes and ten studies for isoflavonoids). The main class of flavonoids investigated for their potential effects on bone metabolism is isoflavonoids because of their structural similarity to estrogen and their ability to bind to the estrogen receptor [89]. Another reason for the higher number of studies for this polyphenol subgroup might be their dietary significance particularly in Asian countries and for vegetarian- and vegan lifestyles.

The sample size of the included studies vary between twelve volunteers [72] and 431 subjects [73] and study durations range from two months [71] to two years [75]. Most studies (except four) conducted a power calculation prior to the beginning of the study.

Apart from that, outcome variables investigated differ broadly. Most studies examined BMD of volunteers $[69,71,73,78]$, whereas other investigators analyzed different markers of bone turnover $[70,72,80]$. Bone turnover markers, such as bone alkaline phosphatase (bAP), aminoterminal propeptide of type I collagen (P1NP), C-telopeptide of type I collagen (CTX), and N-telopeptide of type I collagen (NTX) are beside the BMD good indicators for fracture risk. They are sometimes even stronger associated with this risk than BMD, as they predict fractures in two different ways: (1) the direct reduction of BMD via high bone turnover and (2) independently of BMD, by affecting bone microarchitecture and -fragility [90]. Bone markers are also often used to monitor anti-resorptive therapies and provide a good method for the investigation of nutritional interventions, as changes can be observed more rapidly compared to BMD [90]. As summarized by Eastell et al. early changes in bone turnover markers may be predictive of BMD changes [90]. Reduction of CTX- and NTX concentrations, for instance after six months predict an increase in lumbar spine BMD 2.5-4 years later and an increase of P1NP after three months is associated with changes in lumbar spine BMD after 18 months [90]. For shorter intervention periods (two to three months) it, therefore, might be reasonable to accompany the investigation of BMD with the examination of bone turnover markers as BMD changes might not be observed at this time point. Six of the nine studies that investigated the effects of BMD and bone turnover markers observed similar effects on these parameters (e.g., no changes for both outcomes) [75-78,81,86-88]. Three studies investigating both outcomes showed contradictory results [71,83-85]. Law et al. did not find any changes in total body BMD but observed a reduction in the bone formation marker bAP after consumption of $100 \mathrm{ml}$ onion juice per day for two months [71]. The study duration might not be long enough to already see changes in BMD. Hooshmand et al. found an increase of ulna- and spine BMD after one year of dried plum consumption [84,85]. The changes for OPG and sclerostin they observed were not statistically significant but showed a trend in the same direction $[84,85]$.

Studies examining the effects on bone metabolism in healthy volunteers (prevention of bone loss) did not find any beneficial effects [71-73,78,79,82]. Only one study investigating the effects in healthy women found a smaller reduction in whole-body BMD after 2 years of soy isoflavonoid supplementation $(120 \mathrm{mg} / \mathrm{d})$ compared to placebo [83]. However, the authors stated that the difference only translates to a minimal clinical effect and the supplementation did neither slow bone loss at key fracture sites nor affected bone marker concentrations [83]. Studies that investigated the effect of polyphenols as a treatment for osteopenic women (therapeutic effect) observed a positive impact on bone metabolism $[70,75,84,86]$. One might speculate that polyphenols may only have a therapeutic- but no preventive effect. However, further studies are needed to investigate and confirm this observation.

Doses applied show a high variation between the different studies (several mg up to $1 \mathrm{~g}$ per day). Results, however, do not indicate a dose-dependent effect, as 843 mg EGCG did not affect BMD [69], whereas $54 \mathrm{mg}$ genistein improved BMD [75,76]. It has to be taken into account that we here compare different polyphenol subgroups. They might have a different potency and therefore different doses are needed.

Variations in study population (ethical background and age of participants), habitual diet (substituted polyphenols might not have an additional effect if volunteers already have a balanced 
diet), and lifestyle factors such as physical activity are other factors that might impact study results and lead to contrary findings.

A comparison between human- and animal studies shows that human intervention studies did not consistently confirm the beneficial effects found in animal models. The transferability of results from animal models to humans, however, is limited, because of differences in e.g., physiology, metabolism and bioavailability. It is likely that animals and humans metabolize polyphenols differently. This has to be considered in the evaluation of these results. Moreover, supra-nutritional doses are mostly used in animal studies and these amounts are not attainable within a plant-based diet by humans.

The bioavailability might be a further explanation of inconsistent study results. Bioavailability of polyphenols depends on external (e.g., food related factors and chemical structure) and internal factors (gender, age, colonic microflora, etc.) [91]. Interactions with other food components, such as fat, proteins, or other polyphenols, for instance, can affect the bioavailability of a single compound [92]. This is important for the valuation, particularly, of those studies investigating the effects of a single compound on bone metabolism. The presence of other polyphenols for example seems to increase the polyphenol bioavailability [92]. Therefore, it might be interesting to investigate whether the effective dose of single compounds can be reduced if they are applied with other polyphenols or as polyphenols-rich foods.

\section{Conclusions}

Obviously, recent intervention studies investigating the effects of nutritive polyphenols, either ingested via food or given as single compounds, on bone health showed inconsistent results. Consequently, final conclusions cannot be drawn. Differences in study population, habitual diet, lifestyle factors, and polyphenol bioavailability complicate the comparison of study outcomes. Future studies should take these confounding factors into account. Moreover, it might be of specific interest to evaluate whether the application of polyphenol mixtures (supplements) can lead to beneficial synergistic effects.

Author Contributions: K.A. conducted literature search and prepared the draft manuscript. M.H., N.B. and P.S. contributed to data interpretation; all authors reviewed and edited the manuscript. All authors have read and approved the final manuscript.

Funding: This work was funded by the Federal Ministry of Economics and Energy (BMWi) through the German Aerospace Center (DLR e.V.) grant number 50WB1535.

Conflicts of Interest: The authors declare no conflict of interest.

\section{References}

1. Almeida, M.; O’Brien, C.A. Basic biology of skeletal aging: Role of stress response pathways. J. Gerontol. A Biol. Sci. Med. Sci. 2013, 68, 1197-1208. [CrossRef] [PubMed]

2. Raggatt, L.J.; Partridge, N.C. Cellular and molecular mechanisms of bone remodeling. J. Biol. Chem. 2010, 285, 25103-25108. [CrossRef] [PubMed]

3. Akesson, K. Biochemical markers of bone turnover: A review. Acta Orthop. Scand. 2009, 66, 376-386. [CrossRef]

4. Christen, P.; Ito, K.; Ellouz, R.; Boutroy, S.; Sornay-Rendu, E.; Chapurlat, R.D.; van Rietbergen, B. Bone remodelling in humans is load-driven but not lazy. Nat. Commun. 2014, 5, 4855. [CrossRef] [PubMed]

5. Hadjidakis, D.J.; Androulakis, I.I. Bone remodeling. Ann. N. Y. Acad. Sci. 2006, 1092, 385-396. [CrossRef]

6. Turner, C.H.; Robling, A.G. Mechanical loading and bone formation. IBMS Bonekey 2004, 1, 15-23. [CrossRef]

7. Banfi, G.; Iorio, E.L.; Corsi, M.M. Oxidative stress, free radicals and bone remodeling. Clin. Chem. Lab. Med. 2008, 46, 1550-1555. [CrossRef]

8. Wauquier, F.; Leotoing, L.; Coxam, V.; Guicheux, J.; Wittrant, Y. Oxidative stress in bone remodelling and disease. Trends Mol. Med. 2009, 15, 468-477. [CrossRef]

9. Bai, X.C.; Lu, D.; Liu, A.L.; Zhang, Z.M.; Li, X.M.; Zou, Z.P.; Zeng, W.S.; Cheng, B.L.; Luo, S.Q. Reactive oxygen species stimulates receptor activator of NF-kappaB ligand expression in osteoblast. J. Biol. Chem. 2005, 280, 17497-17506. [CrossRef] 
10. Garrett, I.R.; Boyce, B.F.; Oreffo, R.O.; Bonewald, L.; Poser, J.; Mundy, G.R. Oxygen-derived free radicals stimulate osteoclastic bone resorption in rodent bone in vitro and in vivo. J. Clin. Investig. 1990, 85, 632-639. [CrossRef]

11. Ha, H.; Kwak, H.B.; Lee, S.W.; Jin, H.M.; Kim, H.M.; Kim, H.H.; Lee, Z.H. Reactive oxygen species mediate RANK signaling in osteoclasts. Exp. Cell Res. 2004, 301, 119-127. [CrossRef] [PubMed]

12. Lee, N.K.; Choi, Y.G.; Baik, J.Y.; Han, S.Y.; Jeong, D.-W.; Bae, Y.S.; Kim, N.; Lee, S.Y. A crucial role for reactive oxygen species in RANKL-induced osteoclast differentiation. Blood 2005, 106, 852-859. [CrossRef] [PubMed]

13. Key, L.L., Jr.; Wolf, W.C.; Gundberg, C.M.; Ries, W.L. Superoxide and bone resorption. Bone 1994, 15, 431-436. [PubMed]

14. Yang, S.; Ries, W.L.; Key, L.L., Jr. Nicotinamide adenine dinucleotide phosphate oxidase in the formation of superoxide in osteoclasts. Calcif. Tissue Int. 1998, 63, 346-350. [CrossRef] [PubMed]

15. Sontakke, A.N.; Tare, R.S. A duality in the roles of reactive oxygen species with respect to bone metabolism. Clin. Chim. Acta 2002, 318, 145-148. [CrossRef]

16. Basu, S.; Michaelsson, K.; Olofsson, H.; Johansson, S.; Melhus, H. Association between oxidative stress and bone mineral density. Biochem. Biophys. Res. Commun. 2001, 288, 275-279. [CrossRef] [PubMed]

17. Cervellati, C.; Bonaccorsi, G.; Cremonini, E.; Romani, A.; Fila, E.; Castaldini, M.C.; Ferrazzini, S.; Giganti, M.; Massari, L. Oxidative stress and bone resorption interplay as a possible trigger for postmenopausal osteoporosis. Biomed. Res. Int. 2014, 2014, 569563. [CrossRef]

18. Sanchez-Rodriguez, M.A.; Ruiz-Ramos, M.; Correa-Munoz, E.; Mendoza-Nunez, V.M. Oxidative stress as a risk factor for osteoporosis in elderly Mexicans as characterized by antioxidant enzymes. BMC Musculoskelet. Disord. 2007, 8, 124. [CrossRef]

19. Yalin, S.; Bagis, S.; Polat, G.; Dogruer, N.; Cenk, A.S.; Hatungil, R.; Erdogan, C. Is there a role of free oxygen radicals in primary male osteoporosis? Clin. Exp. Rheumatol. 2005, 23, 689-692.

20. Halliwell, B. Antioxidants in human health and disease. Annu. Rev. Nutr. 1996, 16, 33-50. [CrossRef]

21. de Haan, J.B.; Cristiano, F.; Iannello, R.; Bladier, C.; Kelner, M.J.; Kola, I. Elevation in the ratio of $\mathrm{Cu} / \mathrm{Zn}$-superoxide dismutase to glutathione peroxidase activity induces features of cellular senescence and this effect is mediated by hydrogen peroxide. Hum. Mol. Genet. 1996, 5, 283-292. [CrossRef] [PubMed]

22. Fraser, J.H.; Helfrich, M.H.; Wallace, H.M.; Ralston, S.H. Hydrogen peroxide, but not superoxide, stimulates bone resorption in mouse calvariae. Bone 1996, 19, 223-226. [CrossRef]

23. Mody, N.; Parhami, F.; Sarafian, T.A.; Demer, L.L. Oxidative stress modulates osteoblastic differentiation of vascular and bone cells. Free Radic. Biol. Med. 2001, 31, 509-519. [CrossRef]

24. Benetou, V.; Orfanos, P.; Feskanich, D.; Michaëlsson, K.; Pettersson-Kymmer, U.; Eriksson, S.; Grodstein, F.; Wolk, A.; Bellavia, A.; Ahmed, L.A.; et al. Fruit and Vegetable Intake and Hip Fracture Incidence in Older Men and Women: The CHANCES Project. J. Bone Miner. Res. Off. J. Am. Soc. Bone Miner. Res. 2016, 31, 1743-1752. [CrossRef] [PubMed]

25. Byberg, L.; Bellavia, A.; Orsini, N.; Wolk, A.; Michaëlsson, K. Fruit and vegetable intake and risk of hip fracture: A cohort study of Swedish men and women. J. Bone Miner. Res. Off. J. Am. Soc. Bone Miner. Res. 2015, 30, 976-984. [CrossRef] [PubMed]

26. Qiu, R.; Cao, W.-T.; Tian, H.-Y.; He, J.; Chen, G.-D.; Chen, Y.-M. Greater Intake of Fruit and Vegetables Is Associated with Greater Bone Mineral Density and Lower Osteoporosis Risk in Middle-Aged and Elderly Adults. PLoS ONE 2017, 12, e0168906. [CrossRef]

27. Messina, M. Soy foods, isoflavones, and the health of postmenopausal women. Am. J. Clin. Nutr. 2014, 100, 423-430. [CrossRef] [PubMed]

28. Zheng, X.; Lee, S.-K.; Chun, O.K. Soy Isoflavones and Osteoporotic Bone Loss: A Review with an Emphasis on Modulation of Bone Remodeling. J. Med. Food 2016, 19, 1-14. [CrossRef]

29. Hamdi Kara, I.; Aydin, S.; Gemalmaz, A.; Aktürk, Z.; Yaman, H.; Bozdemir, N.; Kurdak, H.; Sitmapinar, K.; Devran Sencar, I.; Başak, O.; et al. Habitual tea drinking and bone mineral density in postmenopausal Turkish women: Investigation of prevalence of postmenopausal osteoporosis in Turkey (IPPOT Study). Int. J. Vitam. Nutr. Res. 2007, 77, 389-397. [CrossRef] [PubMed]

30. Hossein-nezhad, A.; Maghbooli, Z.; Shafaie, A.R.; Javadi, E.; Larijani, B. Relationship between Tea drinking and Bone Mineral Density in Iranian population. Iran. J. Public Health 2007, 57-62. 
31. Keramat, A.; Patwardhan, B.; Larijani, B.; Chopra, A.; Mithal, A.; Chakravarty, D.; Adibi, H.; Khosravi, A. The assessment of osteoporosis risk factors in Iranian women compared with Indian women. BMC Musculoskelet. Disord. 2008, 9, 28. [CrossRef] [PubMed]

32. Myers, G.; Prince, R.L.; Kerr, D.A.; Devine, A.; Woodman, R.J.; Lewis, J.R.; Hodgson, J.M. Tea and flavonoid intake predict osteoporotic fracture risk in elderly Australian women: A prospective study. Am. J. Clin. Nutr. 2015, 102, 958-965. [CrossRef] [PubMed]

33. Zeng, F.-F.; Wu, B.-H.; Fan, F.; Xie, H.-L.; Xue, W.-Q.; Zhu, H.-L.; Chen, Y.-M. Dietary patterns and the risk of hip fractures in elderly Chinese: A matched case-control study. J. Clin. Endocrinol. Metab. 2013, 98, 2347-2355. [CrossRef]

34. Shen, C.-L.; Chyu, M.-C. Tea flavonoids for bone health: From animals to humans. J. Investig. Med. Off. Publ. Am. Fed. Clin. Res. 2016, 64, 1151-1157. [CrossRef]

35. New, S.A.; Robins, S.P.; Campbell, M.K.; Martin, J.C.; Garton, M.J.; Bolton-Smith, C.; Grubb, D.A.; Lee, S.J.; Reid, D.M. Dietary influences on bone mass and bone metabolism: Further evidence of a positive link between fruit and vegetable consumption and bone health? Am. J. Clin. Nutr. 2000, 71, 142-151. [CrossRef]

36. Wood, A.D.; Macdonald, H.M. Interactions of Dietary Patterns, Systemic Inflammation, and Bone Health. In Nutritional Influences on Bone Health; Burckhardt, P., Dawson-Hughes, B., Weaver, C.M., Eds.; Springer: London, UK, 2013; pp. 19-30.

37. Hardcastle, A.C.; Aucott, L.; Reid, D.M.; Macdonald, H.M. Associations between dietary flavonoid intakes and bone health in a Scottish population. J. Bone Miner. Res. Off. J. Am. Soc. Bone Miner. Res. 2011, 26, 941-947. [CrossRef]

38. Murphy, M.M.; Barraj, L.M.; Herman, D.; Bi, X.; Cheatham, R.; Randolph, R.K. Phytonutrient intake by adults in the United States in relation to fruit and vegetable consumption. J. Acad. Nutr. Diet. 2012, 112, 222-229. [CrossRef]

39. Scalbert, A.; Morand, C.; Manach, C.; Rémésy, C. Absorption and metabolism of polyphenols in the gut and impact on health. Biomed. Pharmacother. 2002, 56, 276-282. [CrossRef]

40. Scalbert, A.; Manach, C.; Morand, C.; Remesy, C.; Jimenez, L. Dietary polyphenols and the prevention of diseases. Crit. Rev. Food Sci. Nutr. 2005, 45, 287-306. [CrossRef]

41. Zhang, Y.-J.; Gan, R.-Y.; Li, S.; Zhou, Y.; Li, A.-N.; Xu, D.-P.; Li, H.-B. Antioxidant Phytochemicals for the Prevention and Treatment of Chronic Diseases. Molecules 2015, 20, 21138-21156. [CrossRef]

42. Hu, B.; Yu, B.; Tang, D.; Li, S.; Wu, Y. Daidzein promotes osteoblast proliferation and differentiation in OCT1 cells through stimulating the activation of BMP-2/Smads pathway. Genet. Mol. Res. GMR 2016, 15, 15028792. [CrossRef] [PubMed]

43. Kim, H.-S.; Suh, K.S.; Sul, D.; Kim, B.-J.; Lee, S.K.; Jung, W.-W. The inhibitory effect and the molecular mechanism of glabridin on RANKL-induced osteoclastogenesis in RAW264.7 cells. Int. J. Mol. Med. 2012, 29, 169-177. [PubMed]

44. Ko, C.H.; Siu, W.S.; Wong, H.L.; Shum, W.T.; Fung, K.P.; San Lau, C.B.; Leung, P.C. Pro-bone and antifat effects of green tea and its polyphenol, epigallocatechin, in rat mesenchymal stem cells in vitro. J. Agric. Food Chem. 2011, 59, 9870-9876. [CrossRef] [PubMed]

45. Moriwaki, S.; Suzuki, K.; Muramatsu, M.; Nomura, A.; Inoue, F.; Into, T.; Yoshiko, Y.; Niida, S. Delphinidin, one of the major anthocyanidins, prevents bone loss through the inhibition of excessive osteoclastogenesis in osteoporosis model mice. PLoS ONE 2014, 9, e97177. [CrossRef] [PubMed]

46. Nash, L.A.; Sullivan, P.J.; Peters, S.J.; Ward, W.E. Rooibos flavonoids, orientin and luteolin, stimulate mineralization in human osteoblasts through the Wnt pathway. Mol. Nutr. Food Res. 2015, 59, 443-453. [CrossRef] [PubMed]

47. Shen, C.-L.; Cao, J.J.; Dagda, R.Y.; Chanjaplammootil, S.; Lu, C.; Chyu, M.-C.; Gao, W.; Wang, J.-S.; Yeh, J.K. Green tea polyphenols benefits body composition and improves bone quality in long-term high-fat diet-induced obese rats. Nutr. Res. 2012, 32, 448-457. [CrossRef] [PubMed]

48. Shen, C.-L.; Yeh, J.K.; Cao, J.J.; Tatum, O.L.; Dagda, R.Y.; Wang, J.-S. Green tea polyphenols mitigate bone loss of female rats in a chronic inflammation-induced bone loss model. J. Nutr. Biochem. 2010, 21, 968-974. [CrossRef] [PubMed]

49. Wang, D.; Ma, W.; Wang, F.; Dong, J.; Wang, D.; Sun, B.; Wang, B. Stimulation of Wnt/beta-Catenin Signaling to Improve Bone Development by Naringin via Interacting with AMPK and Akt. Cell. Physiol. Biochem. Int. J. Exp. Cell. Physiol. Biochem. Pharmacol. 2015, 36, 1563-1576. [CrossRef] [PubMed] 
50. Zhang, X.; Zhou, C.; Zha, X.; Xu, Z.; Li, L.; Liu, Y.; Xu, L.; Cui, L.; Xu, D.; Zhu, B. Apigenin promotes osteogenic differentiation of human mesenchymal stem cells through JNK and p38 MAPK pathways. Mol. Cell. Biochem. 2015, 407, 41-50. [CrossRef]

51. Crozier, A.; Jaganath, I.B.; Clifford, M.N. Dietary phenolics: Chemistry, bioavailability and effects on health. Nat. Prod. Rep. 2009, 26, 1001-1043. [CrossRef]

52. Williamson, G.; Holst, B. Dietary reference intake (DRI) value for dietary polyphenols: Are we heading in the right direction? Br. J. Nutr. 2008, 99, 8. [CrossRef] [PubMed]

53. Hollman, P.C.H.; Arts, I.C.W. Flavonols, flavones and flavanols - nature, occurrence and dietary burden. J. Sci. Food Agric. 2000, 80, 1081-1093. [CrossRef]

54. Aherne, S.A.; O’Brien, N.M. Dietary flavonols: Chemistry, food content, and metabolism. Nutrition 2002, 18, 75-81. [CrossRef]

55. Ross, J.A.; Kasum, C.M. Dietary flavonoids: Bioavailability, metabolic effects, and safety. Annu. Rev. Nutr. 2002, 22, 19-34. [CrossRef] [PubMed]

56. Manach, C.; Morand, C.; Gil-Izquierdo, A.; Bouteloup-Demange, C.; Remesy, C. Bioavailability in humans of the flavanones hesperidin and narirutin after the ingestion of two doses of orange juice. Eur. J. Clin. Nutr. 2003, 57, 235-242. [CrossRef] [PubMed]

57. Tomas-Barberan, F.A.; Clifford, M.N. Flavanones, chalcones and dihydrochalcones-Nature, occurrence and dietary burden. J. Sci. Food Agric. 2000, 80, 1073-1080. [CrossRef]

58. Cao, J.; Chen, W.; Zhang, Y.; Zhang, Y.; Zhao, X. Content of Selected Flavonoids in 100 Edible Vegetables and Fruits. Food Sci. Technol. Res. 2010, 16, 395-402. [CrossRef]

59. Lopez-Lazaro, M. Distribution and Biological Activities of the Flavonoid Luteolin. Mini Rev. Med. Chem. 2009, 9, 31-59. [CrossRef]

60. Mazur, W.M.; Duke, J.A.; Wähälä, K.; Rasku, S.; Adlercreutz, H. Isoflavonoids and Lignans in Legumes: Nutritional and Health Aspects in Humans 11The method development and synthesis of the standards and deuterium-labelled compounds was supported by National Institutes of Health Grants No. 1 R01 CA56289-01 and No. 2 R01 CA56289-04, and analytical work by the EU research contract FAIR-CT95-0894. J. Nutr. Biochem. 1998, 9, 193-200.

61. Kim, H.-S.; Suh, K.S.; Ko, A.; Sul, D.; Choi, D.; Lee, S.K.; Jung, W.-W. The flavonoid glabridin attenuates 2-deoxy-D-ribose-induced oxidative damage and cellular dysfunction in MC3T3-E1 osteoblastic cells. Int. J. Mol. Med. 2013, 31, 243-251. [CrossRef]

62. Scalbert, A.; Williamson, G. Dietary intake and bioavailability of polyphenols. J. Nutr. 2000, 130, $2073-2085$. [CrossRef] [PubMed]

63. Clifford, M.N. Anthocyanins - nature, occurrence and dietary burden. J. Sci. Food Agric. 2000, 80, $1063-1072$. [CrossRef]

64. Stalmach, A. Bioavailability of Dietary Anthocyanins and Hydroxycinnamic Acid. In Polyphenols in Human Health and Disease; Watson, R.R., Preedy, V.R., Zibadi, S., Eds.; Elsevier Acad. Press: Amsterdam, The Netherlands, 2014.

65. Manach, C.; Scalbert, A.; Morand, C.; Remesy, C.; Jimenez, L. Polyphenols: Food sources and bioavailability. Am. J. Clin. Nutr. 2004, 79, 727-747. [CrossRef] [PubMed]

66. Celep, G.S.; Rastmanesh, R.; Marotta, F. Microbial Metabolism of Polyphenols and Health. In Polyphenols in Human Health and Disease; Watson, R.R., Preedy, V.R., Zibadi, S., Eds.; Elsevier Acad. Press: Amsterdam, The Netherlands, 2014.

67. Martinez-Ortega, M.V.; Carcia-Parrilla, M.C.; Troncoso, A.M. Resveratrol content in wines and musts from the south of Spain. Die Nahr. 2000, 44, 253-256. [CrossRef]

68. Jadad, A.R.; Moore, R.A.; Carroll, D.; Jenkinson, C.; Reynolds, D.J.; Gavaghan, D.J.; McQuay, H.J. Assessing the quality of reports of randomized clinical trials: Is blinding necessary? Control. Clin. Trials 1996, 17, 1-12. [CrossRef]

69. Dostal, A.M.; Arikawa, A.; Espejo, L.; Kurzer, M.S. Long-Term Supplementation of Green Tea Extract Does Not Modify Adiposity or Bone Mineral Density in a Randomized Trial of Overweight and Obese Postmenopausal Women. J. Nutr. 2016, 146, 256-264. [CrossRef]

70. Shen, C.-L.; Chyu, M.-C.; Yeh, J.K.; Zhang, Y.; Pence, B.C.; Felton, C.K.; Brismee, J.-M.; Arjmandi, B.H.; Doctolero, S.; Wang, J.-S. Effect of green tea and Tai Chi on bone health in postmenopausal osteopenic women: A 6-month randomized placebo-controlled trial. Osteoporos. Int. 2012, 23, 1541-1552. [CrossRef] [PubMed] 
71. Law, Y.-Y.; Chiu, H.-F.; Lee, H.-H.; Shen, Y.-C.; Venkatakrishnan, K.; Wang, C.-K. Consumption of onion juice modulates oxidative stress and attenuates the risk of bone disorders in middle-aged and post-menopausal healthy subjects. Food Funct. 2016, 7, 902-912. [CrossRef]

72. Martin, B.R.; McCabe, G.P.; McCabe, L.; Jackson, G.S.; Horcajada, M.N.; Offord-Cavin, E.; Peacock, M.; Weaver, C.M. Effect of Hesperidin with and Without a Calcium (Calcilock) Supplement on Bone Health in Postmenopausal Women. J. Clin. Endocrinol. Metab. 2016, 101, 923-927. [CrossRef]

73. Alekel, D.L.; van Loan, M.D.; Koehler, K.J.; Hanson, L.N.; Stewart, J.W.; Hanson, K.B.; Kurzer, M.S.; Peterson, C.T. The soy isoflavones for reducing bone loss (SIRBL) study: A 3-y randomized controlled trial in postmenopausal women. Am. J. Clin. Nutr. 2010, 91, 218-230. [CrossRef]

74. Shedd-Wise, K.M.; Alekel, D.L.; Hofmann, H.; Hanson, K.B.; Schiferl, D.J.; Hanson, L.N.; van Loan, M.D. The soy isoflavones for reducing bone loss study: 3-yr effects on pQCT bone mineral density and strength measures in postmenopausal women. J. Clin. Densitom. Off. J. Int. Soc. Clin. Densitom. 2011, 14, 47-57. [CrossRef] [PubMed]

75. Arcoraci, V.; Atteritano, M.; Squadrito, F.; D'Anna, R.; Marini, H.; Santoro, D.; Minutoli, L.; Messina, S.; Altavilla, D.; Bitto, A. Antiosteoporotic Activity of Genistein Aglycone in Postmenopausal Women: Evidence from a Post-Hoc Analysis of a Multicenter Randomized Controlled Trial. Nutrients 2017, 9, 179. [CrossRef] [PubMed]

76. Marini, H.; Bitto, A.; Altavilla, D.; Burnett, B.P.; Polito, F.; Di Stefano, V.; Minutoli, L.; Atteritano, M.; Levy, R.M.; D'Anna, R.; et al. Breast safety and efficacy of genistein aglycone for postmenopausal bone loss: A follow-up study. J. Clin. Endocrinol. Metab. 2008, 93, 4787-4796. [CrossRef]

77. Marini, H.; Minutoli, L.; Polito, F.; Bitto, A.; Altavilla, D.; Atteritano, M.; Gaudio, A.; Mazzaferro, S.; Frisina, A.; Frisina, N.; et al. OPG and sRANKL serum concentrations in osteopenic, postmenopausal women after 2-year genistein administration. J. Bone Miner. Res. Off. J. Am. Soc. Bone Miner. Res. 2008, 23, 715-720. [CrossRef]

78. Brink, E.; Coxam, V.; Robins, S.; Wahala, K.; Cassidy, A.; Branca, F. Long-term consumption of isoflavone-enriched foods does not affect bone mineral density, bone metabolism, or hormonal status in early postmenopausal women: A randomized, double-blind, placebo controlled study. Am. J. Clin. Nutr. 2008, 87, 761-770. [CrossRef]

79. Kenny, A.M.; Mangano, K.M.; Abourizk, R.H.; Bruno, R.S.; Anamani, D.E.; Kleppinger, A.; Walsh, S.J.; Prestwood, K.M.; Kerstetter, J.E. Soy proteins and isoflavones affect bone mineral density in older women: A randomized controlled trial. Am. J. Clin. Nutr. 2009, 90, 234-242. [CrossRef]

80. Sathyapalan, T.; Aye, M.; Rigby, A.S.; Fraser, W.D.; Thatcher, N.J.; Kilpatrick, E.S.; Atkin, S.L. Soy Reduces Bone Turnover Markers in Women During Early Menopause: A Randomized Controlled Trial. J. Bone Miner. Res. Off. J. Am. Soc. Bone Miner. Res. 2017, 32, 157-164. [CrossRef] [PubMed]

81. Tai, T.Y.; Tsai, K.S.; Tu, S.T.; Wu, J.S.; Chang, C.I.; Chen, C.L.; Shaw, N.S.; Peng, H.Y.; Wang, S.Y.; Wu, C.H. The effect of soy isoflavone on bone mineral density in postmenopausal Taiwanese women with bone loss: A 2-year randomized double-blind placebo-controlled study. Osteoporos. Int. 2012, 23, 1571-1580. [CrossRef]

82. Vupadhyayula, P.M.; Gallagher, J.C.; Templin, T.; Logsdon, S.M.; Smith, L.M. Effects of soy protein isolate on bone mineral density and physical performance indices in postmenopausal women-A 2-year randomized, double-blind, placebo-controlled trial. Menopause 2009, 16, 320-328. [CrossRef]

83. Wong, W.W.; Lewis, R.D.; Steinberg, F.M.; Murray, M.J.; Cramer, M.A.; Amato, P.; Young, R.L.; Barnes, S.; Ellis, K.J.; Shypailo, R.J.; et al. Soy isoflavone supplementation and bone mineral density in menopausal women: A 2-y multicenter clinical trial. Am. J. Clin. Nutr. 2009, 90, 1433-1439. [CrossRef]

84. Hooshmand, S.; Chai, S.C.; Saadat, R.L.; Payton, M.E.; Brummel-Smith, K.; Arjmandi, B.H. Comparative effects of dried plum and dried apple on bone in postmenopausal women. Br. J. Nutr. 2011, 106, 923-930. [CrossRef]

85. Hooshmand, S.; Brisco, J.R.Y.; Arjmandi, B.H. The effect of dried plum on serum levels of receptor activator of NF- $\mathrm{KB}$ ligand, osteoprotegerin and sclerostin in osteopenic postmenopausal women: A randomised controlled trial. Br. J. Nutr. 2014, 112, 55-60. [CrossRef] [PubMed]

86. Hooshmand, S.; Kern, M.; Metti, D.; Shamloufard, P.; Chai, S.C.; Johnson, S.A.; Payton, M.E.; Arjmandi, B.H. The effect of two doses of dried plum on bone density and bone biomarkers in osteopenic postmenopausal women: A randomized, controlled trial. Osteoporos. Int. 2016, 27, 2271-2279. [CrossRef] [PubMed] 
87. Simonavice, E.; Liu, P.-Y.; Ilich, J.Z.; Kim, J.-S.; Arjmandi, B.; Panton, L.B. The effects of a 6-month resistance training and dried plum consumption intervention on strength, body composition, blood markers of bone turnover, and inflammation in breast cancer survivors. Appl. Physiol. Nutr. Metab. 2014, 39, 730-739. [CrossRef] [PubMed]

88. Ornstrup, M.J.; Harslof, T.; Kjaer, T.N.; Langdahl, B.L.; Pedersen, S.B. Resveratrol increases bone mineral density and bone alkaline phosphatase in obese men: A randomized placebo-controlled trial. J. Clin. Endocrinol. Metab. 2014, 99, 4720-4729. [CrossRef] [PubMed]

89. Weaver, C.M.; Alekel, D.L.; Ward, W.E.; Ronis, M.J. Flavonoid intake and bone health. J. Nutr. Gerontol. Geriatr. 2012, 31, 239-253. [CrossRef]

90. Eastell, R.; Hannon, R.A. Biomarkers of bone health and osteoporosis risk. Proc. Nutr. Soc. 2008, 67, $157-162$. [CrossRef]

91. D'Archivio, M.; Filesi, C.; Varì, R.; Scazzocchio, B.; Masella, R. Bioavailability of the polyphenols: Status and controversies. Int. J. Mol. Sci. 2010, 11, 1321-1342. [CrossRef]

92. Bohn, T. Dietary factors affecting polyphenol bioavailability. Nutr. Rev. 2014, 72, 429-452. [CrossRef]

(C) 2019 by the authors. Licensee MDPI, Basel, Switzerland. This article is an open access article distributed under the terms and conditions of the Creative Commons Attribution (CC BY) license (http://creativecommons.org/licenses/by/4.0/). 